June 1991

\title{
Psychiatry and Psychoanalysis in The Nineties
}

Diane E. Custer, M.D.

Institute of Pennsylvania Hospital, Philadelphia

Follow this and additional works at: https://jdc.jefferson.edu/jeffjpsychiatry

Part of the Psychiatry Commons

Let us know how access to this document benefits you

\section{Recommended Citation}

Custer, M.D., Diane E. (1991) "Psychiatry and Psychoanalysis in The Nineties," Jefferson Journal of Psychiatry. Vol. 9 : Iss. 2 , Article 12.

DOI: https://doi.org/10.29046/JJP.009.2.010

Available at: https://jdc.jefferson.edu/jeffjpsychiatry/vol9/iss2/12

This Article is brought to you for free and open access by the Jefferson Digital Commons. The Jefferson Digital Commons is a service of Thomas Jefferson University's Center for Teaching and Learning (CTL). The Commons is a showcase for Jefferson books and journals, peer-reviewed scholarly publications, unique historical collections from the University archives, and teaching tools. The Jefferson Digital Commons allows researchers and interested readers anywhere in the world to learn about and keep up to date with Jefferson scholarship. This article has been accepted for inclusion in Jefferson Journal of Psychiatry by an authorized administrator of the Jefferson Digital Commons. For more information, please contact: JeffersonDigitalCommons@jefferson.edu. 


\title{
Panel Report
}

The Jefferson Journal of Psychiatry is now accepting reports on meetings and panel discussions for our new "Panel Reports" column. Authors should submit their manuscripts for approval by those who participated in the panel or meeting prior to submission to the Journal for editorial review.

\section{Psychiatry and Psychoanalysis in The Nineties}

\author{
Diane E. Custer, M.D.
}

\begin{abstract}
The Philadelphia Association for Psychoanalysis hosted a panel designed for medical students, psychiatric residents, psychiatrists and other professionals interested in applying psychoanalysic thought and listening skills to areas in general psychiatry. The educational objectives included increasing familiarity with the various components of psychoanalytic listening, (greater skill in making use of psychoanalytic listening in work with patients) and heightened awareness of the varied applications of psychoanalytic listening as a tool in general psychiatric practice.
\end{abstract}

The Philadelphia Association for Psychoanalysis hosted a panel designed for medical students, psychiatric residents, psychiatrists and other professionals interested in applying psychoanalytic thought and listening skills to areas in general psychiatry.

Moderator Bruce J. Levin, M.D. opened the panel by describing two general approaches to patient care in psychiatry in the 1990's. Utilizing advances in neuroscience, one approach searches for the physical and descriptive means to understand patients. Through careful listening, the other approach searches for the emotional contributions to illness. The latter approach of careful psychoanalytic listening has expanded knowledge in psychoneurosis, personality disorders, psychosomatic medicine, group psychology, and child and adolescent psychiatry. Through a personal analysis, psychoanalytic coursework, clinical experience and supervision, psychoanalysts learn to evaluate the manifest content of speech in search of its deeper meaning. Through this method, the analyst uncovers unconscious conflict which gives a greater understanding of the patient to promote further alleviation of suffering. Dr Levin developed the panel discussion to demonstrate that psychoanalytic principles applied 
outside of the formal analytic setting prove useful in other areas of psychiatry by giving greater understanding of psychological pain, conflict, anxiety, and adaptation.

\section{Psychiatry and Psychoanalysis-An Historical Note on Their Relationship}

Emanuel E. Garcia, M.D. discussed the historical relationship between psychiatry and psychoanalysis. He refuted Dr. Melvin Sabshin's criticisms of psychoanalysis in the American Journal of Psychiatry (vol. 147, pp. 1267-1274, 1990), which gave the mistaken impression that psychoanalysis is somehow inherently opposed to psychiatry, and cited Sigmund Freud's comment that "What is opposed to psycho-analysis is not psychiatry but psychiatrists" (Standard Edition, vo. 16, p. 254, 1916-17). Dr. Garcia emphasized Freud's observation that psychiatry is related to psychoanalysis as gross anatomy to histology, that a harmonious and complementary relationship between the two disciplines existed, and that a scientifically-based psychiatry could only be achieved with a knowledge of unconscious mental processes. Information provided by psychoanalysis as a general psychology of the unconscious is applicable to the entire spectrum of psychiatric practice, from the treatment of neurosis to psychosis, perversions to affective illness.

Dr. Garcia also traced a brief history of psychiatry and psychoanalysis, emphasizing the psychiatric reform movement inaugurated by Johan Weier and the momentous development of Freud's ideas through his work with Meynert, Charcot, Bernheim and Breuer. He compared Freud's origination of the technique of free association to Leeuwenhoek's invention of the microscope in providing access to an entirely new realm of observation. Freud's discovery of the similarity of mechanisms at work in the minds of the normal and the mentally ill accomplished a humanistic as well as scientific revolution. According to Dr. Garcia, Freud's exquisite appreciation for psychical reality constituted a landmark in the history of civilization. He advocated the benefits of concentrated listening developed through analytic training for all psychiatric treatment.

\section{Diagnostic Evaluations}

Harvey J. Schwartz, M.D. discussed the applicability of analytic training to diagnostic evaluations. He noted that through analytic receptivity and transiently accepting the distortions in our patients' images of us, we may discover the screens of the past through which they view the world. In order to achieve this psychological accessibility, the analyst must develop skill in self-observation which is possible only when he is freed from the constraining concreteness of unanalyzed aggression. Dr. Schwartz acknowledged the importance of both descriptive and dynamic approaches in his diagnostic work, but pointed out several differences between them.

Unique aspects of a dynamic as distinguished from descriptive evaluation include the role of patient as collaborator, the experience of every encounter as treatment to the patient, and the value of the clinician's feelings as well as the 
patient's free associations which communicate the latent meanings of intrapsychic activity outside of the patient's awareness. Dr. Schwartz discussed a poignant case in which using a dynamic approach permitted him to assist a young woman with terminal cancer. He followed Robert Waelder's guidelines for easing suffering by discovering what the patient unconsciously desired, what she feared, and how she responded to that fear. To accomplish the task of providing the patient an opportunity to observe his own fantasies and wishes relatively guilt free, the therapist needs intimate familiarity with his own unconscious. This familiarity is achieved through personal analysis during analytic training. Dr. Schwartz characterized analytic training as comparable to the classical training of a jazz musician. Analytic training serves as the foundation from which one may improvise to create an exciting, authentic therapeutic style.

\section{In-Patient Psychiatry}

Dr. Levin discussed the benefits of psychoanalytic understanding in treating in-patients. He warned of the perils of recent trends in treatment focusing exclusively on biology, as dictated by some managed care organizations. A patient who, to others appeared unable to benefit from more than mechanical and pharmacologic protection from her self-destructive impulses, worked dynamically to lift repressed material which was driving her behavior. No physical or chemical restraint had been able to achieve the quieting results of a trusting exploration of her dynamic unconscious in collaboration with Dr. Levin. Dr. Levin discussed the benefit of his analytic training in examining issues of countertransference in situations where pressure is exerted on the therapist to satisfy demands made by patients, treatment teams, insurance companies, managed care firms, and his own unconscious. Should these pressures remain unanalyzed, they might interfere with the delivery of optimal care.

\section{Psychopharmacology}

Eva G. Loeb, M.D. discussed the interaction of psychodynamic understanding and psychopharmacology. She stressed the concept of brain-mind duality as crucial to the optimal treatment of patients. Dr. Loeb described three clinical vignettes which revealed some of the critical questions she asks when using pharmacotherapy as a portion of a psychodynamic approach. One such question is "what would I be treating with the drug?". Some patients seek medication as a magical way to erase painful affects from consciousness. Others resist indicated use of psychotropics because of fantasies about the meaning of accepting this form of assistance. Some of Dr. Loeb's most rewarding work occurs when pharmacotherapy for the brain provides access to psychotherapy for the mind.

\section{Child Psychiatry and Administrative Psychiatry}

Joel L. Schwartz, M.D. discussed the importance of psychoanalytic understanding in his roles as child and administrative psychiatrist. Dr. Schwartz finds that 
psychoanalysis unlocks the roadblocks which arrest development in some children. The frequency and intensity of psychoanalysis makes its use in indicated cases of childhood illness ideal in restoring the child to the path of development as quickly as possible. As an administrative psychiatrist, Dr. Schwartz serves as a school consultant and medical director on an in-patient unit. In these roles he interacts with social workers, teachers, residents, nurses, psychiatric technicians, activities and occupational therapists. He uses psychodynamic understanding gained through a personal analysis of his own conflicts and blind spots as well as psychoanalytic coursework to assist him in navigating feelings of the staff and patients encountered in the milieu. He uses an understanding of power structures and personalities to assist him in applying Greenson's principles of confrontation and clarification to promote a therapeutic environment. Dr. Schwartz enjoys the utility of psychoanalytic understanding on a daily basis. He feels that knowledge of himself makes him curious about others and a more effective instrument for positive change.

Members of the audience engaged in a lively question and discussion session with panel members. Several registrants who arrived at the panel as skeptics discussed their greater awareness of the broad scope of successful applications for psychoanalytic listening as a result of their attendance. 